\title{
Effects of broccoli extract on biodistribution and labeling blood components with ${ }^{99}{ }^{\mathrm{m}} \mathrm{Tc}-\mathrm{GH}^{1}$
}

\author{
Efeitos do extrato de brócolis na biodistribuição e marcação dos \\ componentes do sangue com ${ }^{99 \mathrm{~m}} \mathrm{Tc}-\mathrm{GH}$
}

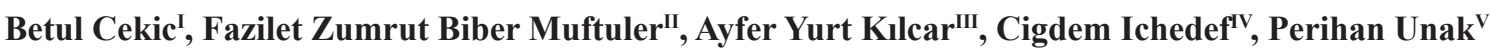 \\ ${ }^{1}$ Research performed at Department of Nuclear Applications, Institute of Nuclear Sciences, Ege University, 35100, Bornova, Izmir-Turkey. \\ I Fellow Master degree, Department of Nuclear Applications, Institute of Nuclear Sciences, Ege University. Carried out the study and drafted the \\ manuscript. \\ II Associate Professor, Department of Nuclear Applications, Institute of Nuclear Sciences, Ege University. Responsible for conception, design, \\ intellectual and scientific content of the study, supervised all phases of the study, manuscript writing and critical revision. \\ III Fellow PhD degree, Research Assistant, Department of Nuclear Applications, Institute of Nuclear Sciences, Ege University. Manuscript writing, \\ involved in technical procedures and animal experiments. \\ ${ }^{\text {Iv }} \mathrm{PhD}$, Research Assistant, Department of Nuclear Applications, Institute of Nuclear Sciences, Ege University. Involved in technical procedures and \\ animal experiments. \\ v PhD, Department of Nuclear Applications, Institute of Nuclear Sciences, Ege University. Compiled the results, critical revision.
}

\begin{abstract}
PURPOSE: People consume vegetables without the knowledge of the side effects of the biological and chemical contents and interactions between radiopharmaceuticals and herbal extract. To this end, current study is focused on the effects of broccoli extract on biodistribution of radiolabeled glucoheptonate $\left({ }^{99 \mathrm{~m}} \mathrm{Tc}-\mathrm{GH}\right)$ and radiolabeling of blood components.

METHODS: GH was labeled with ${ }^{99 \mathrm{~m}} \mathrm{Tc}$. Quality control studies were done utilizing TLC method. Biodistribution studies were performed on male rats which were treated via gavage with either broccoli extract or SF as control group for 15 days. Blood samples were withdrawn from rats' heart. Radiolabeling of blood constituents performed incubating with $\mathrm{GH}, \mathrm{SnCl}_{2}$ and ${ }^{99 \mathrm{~m}} \mathrm{Tc}$.

RESULTS: Radiochemical yield of ${ }^{99} \mathrm{~m}$ Tc-GH is $98.46 \pm 1.48 \%(\mathrm{n}=8)$. Biodistribution studies have shown that according to the control, the treated group with broccoli has approximately 10 times less uptake in kidney. The percentage of the radioactivity ratios of the blood components is found to be same in both groups.

CONCLUSIONS: Although there is no considerable effect on the radiolabeling of blood components, there is an outstanding change on the biodistribution studies especially on kidneys. The knowledge of this change on kidney uptake may contribute to reduce the risk of misdiagnosis and/or repetition of the examinations in Nuclear Medicine.
\end{abstract}

Key words: Brassica. Blood Cells. Plant Preparations. Rats.

\section{RESUMO}

OBJETIVO: As pessoas consomem verduras sem o conhecimento dos efeitos colaterais dos conteúdos biológicos e químicos e interações entre os medicamentos radiofarmacêuticos e os extratos vegetais. Para este fim, o estudo atual é focado sobre os efeitos do extrato de brócolis na biodistribuição do fármaco glucoheptonato ( $\left.{ }^{99 \mathrm{~m}} \mathrm{Tc}-\mathrm{GH}\right)$ e da marcação de componentes do sangue.

MÉTODOS: GH foi marcado com ${ }^{99 \mathrm{~m}} \mathrm{Tc}$. Estudos de controle de qualidade foram feitos utilizando o método do TLC. Os estudos de biodistribuição foram realizados em ratos machos que foram tratados por gavagem com um extrato de brócolis ou SF como grupo controle para 15 dias. Amostras de sangue foram retiradas do coração de ratos. Marcação de constituintes sanguíneos realizados incubação com $\mathrm{SnCl}_{2} \mathrm{GH}$ e ${ }^{99 \mathrm{~m}} \mathrm{Tc}$.

RESULTADOS: Radioquímica rendimento de ${ }^{99 \mathrm{~m}} \mathrm{Tc}-\mathrm{GH}$ é 98,46 $\pm 1,48 \%(\mathrm{n}=8)$. Os estudos de biodistribuição mostraram que de acordo com o controle, o grupo tratado com brócolis tem aproximadamente 10 vezes menor absorção no rim. O percentual do ratio de radioatividade dos componentes do sangue é encontrado para ser igual nos dois grupos.

CONCLUSÕES: Embora não haja nenhum efeito considerável sobre a marcação dos componentes do sangue há uma mudança notável na biodistribuição especialmente nos rins. O conhecimento desta mudança na captação de rim pode contribuir para reduzir o risco de erro diagnóstico e/ou a repetição dos exames de Medicina Nuclear.

Descritores: Brassica. Células Sanguíneas. Preparações de Plantas. Ratos. 


\section{Introduction}

It's known that the consumption of natural foods which have high antioxidant capacity has protective effect on our health. Depending on this knowledge nowadays there is a swift increase in consumption of these natural foods like vegetables and fruits. In epidemiologic studies it's observed that there is an interaction between vegetable consumption and cancer prevention ${ }^{1,2}$.

Biological studies have shown that vegetables in Brassica family could reduce risks of the cancers, especially the gastrointestinal tract cancers ${ }^{3}$. Because of these and similar hypothesis, a great many of the vegetables in Brassica family have been subject of the chemical and biological studies.

Broccoli (Brassica oleracea Italica) from the Brassicaceae family is a nutrient source which contains many bioactive components including glucosinolates, flavonoids, minerals and antioxidants ${ }^{4}$.

In Nuclear Medicine, interactions between herbal extracts and radiopharmaceuticals are not completely understood. Nevertheless patients consume these vegetables without the knowledge of the side effects of biological and/or chemical contents of these vegetables ${ }^{5}$. These contents may cause different variations on the behavior of radiopharmaceuticals. These variations may arise due to various factors including interactions and competition to binding site between herbal extract and radiotracers. It has been already reported that the biodistribution of radiopharmaceuticals used for imaging in Nuclear Medicine is also altered by herbal extracts $^{6,7}$. In these studies, it has seen that some of the herbal extracts could alter uptake of the radiopharmaceuticals by organs, accordingly SPECT and PET scanning results could change. In some other studies it's concluded that drugs such as natural, herbal origin or synthetic drugs, as well as labeling conditions, could be effective on the labeling of blood constituents ${ }^{8}$.

Current study aims to evaluate in vitro and in vivo effects of broccoli extract on the biodistribution of technetium-99m labeled glucoheptonate ( $\left.{ }^{99 \mathrm{~m}} \mathrm{Tc}-\mathrm{GH}\right)$, which used for renal imaging and function testing; also known as ${ }^{99 \mathrm{~m}} \mathrm{Tc}$ glucoceptate.

\section{Methods}

${ }^{99} \mathrm{TcO}_{4}^{-}$was supplied by Monrol, Turkey. All other chemicals were supplied from Merck Chemical Co. and Aldrich Chemical Co. All animal experiments were carried out under the approval of the relevant Institutional Animal Review Committee of Ege University, (Number: 2010-51) Izmir, Turkey.

\section{Extraction of broccoli}

Broccoli was purchased from local market, dried at room temperature and powdered. Powdered samples $(250 \mathrm{mg})$ were extracted with $5 \mathrm{~mL}$ of methanol/water $(60: 40, \mathrm{v} / \mathrm{v})$ using ultrasonic bath (Ceia P104) for $60 \mathrm{~min}$. at room temperature. The slurry mixture was centrifuged at $2500 \mathrm{rpm}$ for $15 \mathrm{~min}$. (Nuve CN180). The supernatant was collected and $5 \mathrm{~mL}$ of methanol/ water $(60: 40, \mathrm{v} / \mathrm{v})$ was added in the remaining parts in the tube. Same procedure was repeated 3 times. All the supernatants collected and kept at $-20{ }^{\circ} \mathrm{C}$ until the day of analyses.

\section{Radiolabeling procedure of $G H$ with ${ }^{99 m} T c$}

Initially, stock solutions of glucoheptonate $(1 \mathrm{mg} / 1 \mathrm{~mL}$ bidistillated water) and $\mathrm{SnCl}_{2}(1 \mathrm{mg} / 1 \mathrm{~mL}$ bidistillated water $)$ were prepared. Then $0.500 \mathrm{~mL} \mathrm{GH}$ and $0.025 \mathrm{~mL} \mathrm{SnCl}_{2}$ were mixed in a tube and $\mathrm{pH}$ was adjusted to 6 via $0.010 \mathrm{M} \mathrm{NaOH}$ solution. Five $\mathrm{mCi}(185 \mathrm{MBq}) / 100 \mu \mathrm{L}$ of ${ }^{99 \mathrm{~m}} \mathrm{TcO}_{4}^{-}$were added into the mixture and incubated $20 \mathrm{~min}$. at room temperature.

\section{Quality control procedures}

High Performance Liquid Chromatography (HPLC): A low pressure gradient HPLC system (LC-10ATvp quaternary pump, SPD-10A/V UV detector, RF-10AXL Fluorescence detector, RAD501 single channel analyzer, a syringe injector equipped with a $1 \mathrm{~mL}$ loop and 7- $\mu \mathrm{m}$ VP 250/21 Nucleosil 1007 C18 column (Macherey - Nagel) was used for the analytical experiments.

HPLC of broccoli extract: Fluorescence was monitored with a model RF-10AXL Shimadzu Fluorescence Detector. The samples were analyzed at a flow rate of $1 \mathrm{~mL} / \mathrm{min}$ and injection volume was $20 \mu \mathrm{L}$. The excitation was monitored at $290 \mathrm{~nm}$ and emission at $360 \mathrm{~nm}$. The mobile phase was consisted of two solvents which were water-formic acid (0.33\%) (A) and methanol (B). The elution gradient profile used was as $10-17 \%$ B in 30 min., $17-40 \%$ B in 10 min., $40-100 \%$ B in 1 min., $100 \%$ B in 5 min..

HPLC of GH: Shimadzu (SPD-10AV) UV-VIS detector was used for this analyze. $1 \mathrm{mg} \mathrm{GH}$ was dissolved in $1 \mathrm{~mL}$ bidistillated water. $10 \%$ acetonitrile in bidistillated water was used as mobile phase. Flow rate was $1 \mathrm{~mL} / \mathrm{min}$. and injection volume was $50 \mu \mathrm{L}$. The chromatogram was recorded at $280 \mathrm{~nm}$.

High Performance Liquid Radio Chromatography (HPLRC): RAD501 single channel analyzer, having a $\mathrm{Cd}(\mathrm{Te})$ solid-state detector was used for this analyze. $10 \%$ acetonitrile in 
bidistillated water was used as mobile phase. The flow rate was set to $1 \mathrm{~mL} / \mathrm{min}$. and the chromatogram was recorded at $280 \mathrm{~nm}$. Retention time (Rt) values of ${ }^{99} \mathrm{mcO}_{4}{ }^{-}$and ${ }^{99 \mathrm{~m}} \mathrm{Tc}-\mathrm{GH}$ were obtained with this procedure.

\section{Thin Layer Chromatography (TLC)}

TLC of broccoli extract: $5 \mu \mathrm{L}$ of broccoli extract was applied on ITLC-SG (Merck-5554) plates. As mobile phase, 60\% methanol in water was used. Then UV lamp was used to determine location of components in extract. Relative front $\left(\mathrm{R}_{\mathrm{f}}\right)$ values of the components were calculated.

TLC of GH: $1 \mathrm{mg} \mathrm{GH}$ was dissolved in $1 \mathrm{~mL}$ bidistillated water. $5 \mu \mathrm{L}$ from this solution was applied on ITLC-SG (Merck-5554) plates. Acetone was used as mobile phase. $R_{f}$ value of GH was determined by using UV lamp.

Thin Layer Radio Chromatography (TLRC): TLRC was performed with ITLC-SG (Merck-5554) using $1.5 \times 10 \mathrm{~cm}$ size plates. Samples of the ${ }^{99 \mathrm{~m}} \mathrm{TcO}_{4}$, , reduced ${ }^{99 \mathrm{~m}} \mathrm{Tc}$ and ${ }^{99 \mathrm{~m}} \mathrm{Tc}-\mathrm{GH}(5$ $\mu \mathrm{L})$ were applied. SF $(0.9 \% \mathrm{NaCl})$ was used as mobile phase to determine the radiochemical purity. Then, the TLRC plates were counted by TLC Scanner (BioscanAR 2000). The $R_{f}$ values and radiolabeling yield were determined.

\section{Stability study of ${ }^{99 m} T c-G H$}

Stability of ${ }^{99 m} \mathrm{Tc}-\mathrm{GH}$ was determined using TLRC method. ${ }^{99 \mathrm{~m}} \mathrm{Tc}-\mathrm{GH}$ was applied on ITLC-SG plates at $0^{\text {th }}, 1^{\text {st }}, 3^{\text {rd }}$, $6^{\text {th }}, 7^{\text {th }}$ and $24^{\text {th }}$ hours. Then their radioactivities were counted.

\section{Lipophilicity $(\log P)$}

${ }^{99 \mathrm{~m}} \mathrm{Tc}-\mathrm{GH}(0.100 \mathrm{~mL})$ was added after $0.250 \mathrm{~mL}$ of $\mathrm{n}$-octanol and $0.250 \mathrm{~mL}$ of phosphate buffer $(\mathrm{pH} 7)$ in a centrifuge tube. Then, this solution was vortexed for $1 \mathrm{~min}$. and centrifuged for $30 \mathrm{~min}$. at $2500 \mathrm{rpm}$. $0.100 \mathrm{~mL}$ aliquots of each phase were taken and counted by $\mathrm{Cd}(\mathrm{Te})$ detector three times. $\log \mathrm{P}$ was calculated proportioning counts of phases. This experimental value of $\log P$ was compared with theoretical LogP which was calculated ACD/ LogP software (Version 6.0 for Microsoft Windows).

\section{Animals treatments}

Male Wistar rats $(n=16)$ were randomly divided into two groups as treated $(n=8)$ and control $(n=8)$ groups. In the treated group $330 \mathrm{mg} / \mathrm{kg}$ broccoli extract was administered to each rat by gavage during 15 days. Control group was treated with saline solution $(0.9 \% \mathrm{NaCl})$ by the same way and period.

\section{Radiolabeling of blood components}

Blood samples were withdrawn from rats' heart under anesthesia [xylazine and ketamine $(75-100 \mathrm{mg} / \mathrm{kg}+5-10 \mathrm{~g} / \mathrm{kg})$ ] and the rats were not sacrificed. $0.500 \mathrm{~mL}$ of blood samples was mixed with $0.500 \mathrm{~mL}(1 \mathrm{mg} / \mathrm{mL}) \mathrm{GH}$ and $0.010 \mathrm{~mL}(1 \mathrm{mg} / \mathrm{mL})$ $\mathrm{SnCl}_{2}$ and incubated $10 \mathrm{~min}$.. Then $1 \mathrm{mCi}(37 \mathrm{MBq}){ }^{99 \mathrm{~m}} \mathrm{Tc}$ was added and incubated $10 \mathrm{~min}$.. These samples were centrifuged and the components [serum (S) - blood cells (BC)] separated. The samples was counted by $\mathrm{Cd}(\mathrm{Te})$ detector and the percentage of radioactivity was calculated. The data were expressed as mean \pm standard deviation of the percentage of radioactivity (Table 3 ).

\section{Biodistribution of ${ }^{99 m} T c-G H$}

At the end of 15 days, ${ }^{99 \mathrm{~m}} \mathrm{Tc}-\mathrm{GH}(0.200 \mathrm{~mL})$ was injected into the tail vein of the rats. The rats were euthanized by injection of sodium pentobarbital $(200 \mathrm{mg} / \mathrm{kg})$ by intraperitoneal via. After euthanasia, the organs were isolated and weighed (heart, lung, liver, kidney, small intestine, large intestine, stomach, spleen, pancreas, muscle, head, fat, thyroid, bladder, blood, testis, prostate and bone) and counted by $\mathrm{Cd}(\mathrm{Te})$ detector. The percentage of injected dose per gram of tissue weight $(\% \mathrm{ID} / \mathrm{g})$ was determined.

\section{Statistical analysis}

Differences in the mean values of the measured activities were evaluated statistically by the SPSS 13 program (Univariate Variance Analyses and Pearson Correlation). Probability values $<0.05$ were considered as significant. Pearson correlation was carried out among different organs for ${ }^{99 \mathrm{~m}} \mathrm{Tc}-\mathrm{GH}$.

\section{Results}

Quality control studies of broccoli extract and GH were performed by HPLC and TLC. The relevant chromatograms were given in Figures 1 and 2. 


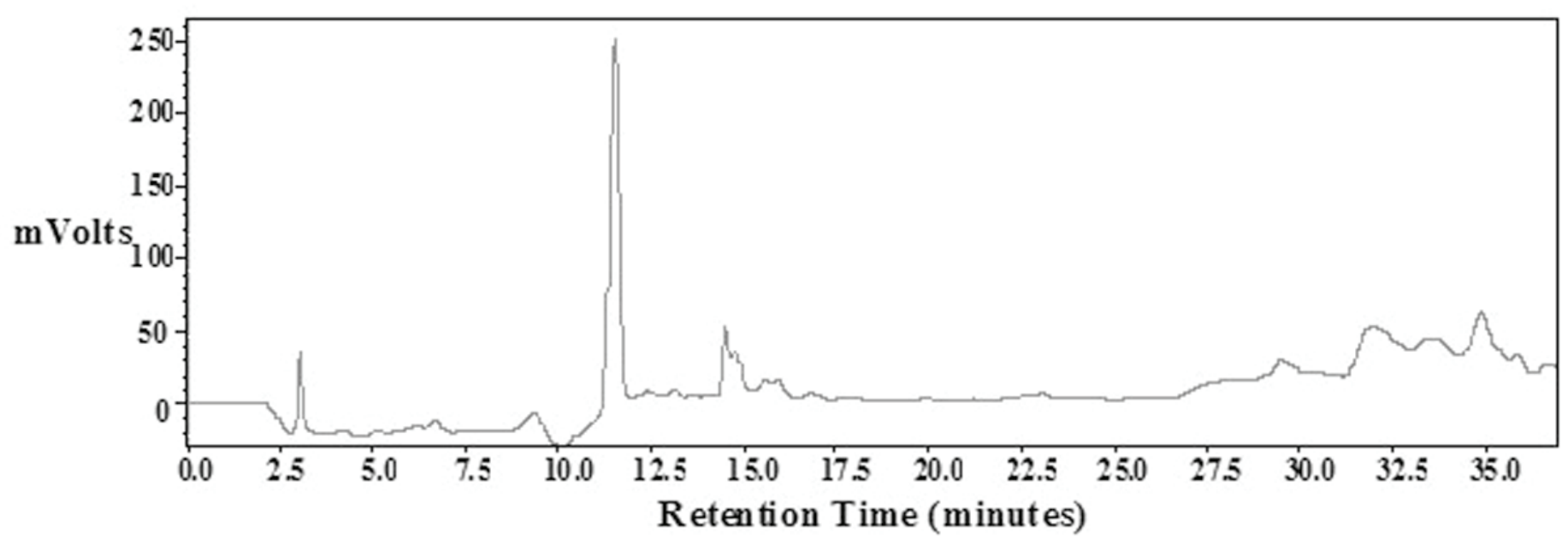

FIGURE 1 - HPLC chromatogram of broccoli extract.

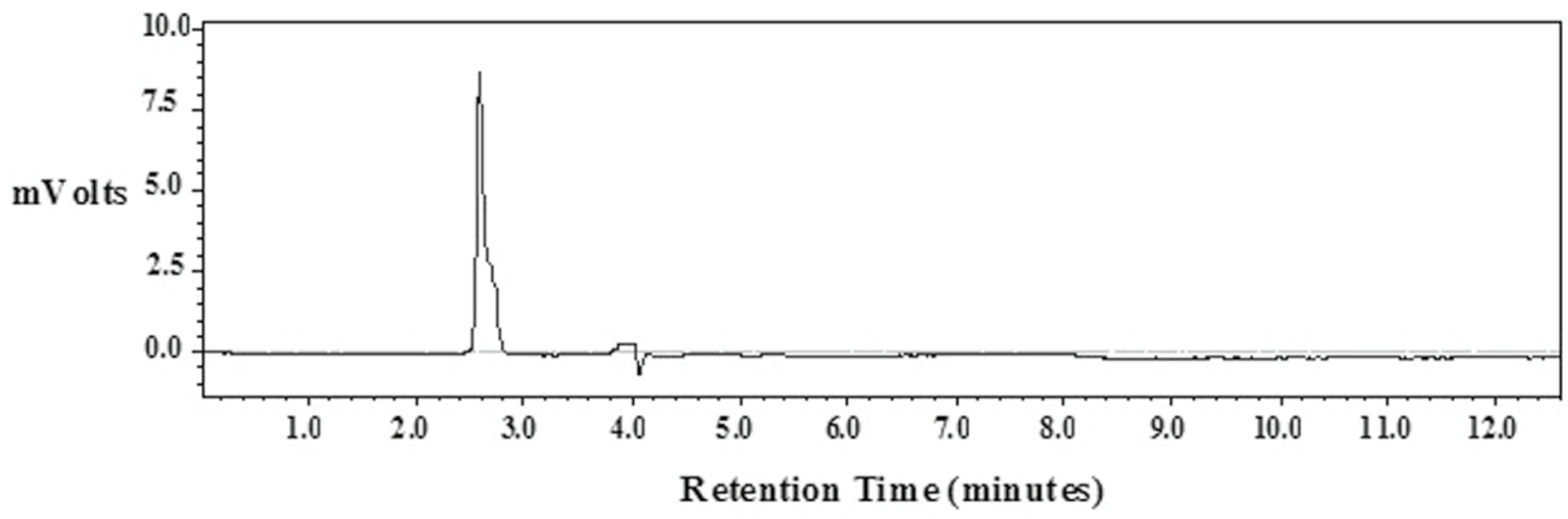

FIGURE 2 - HPLC chromatogram of GH.

According to HPLC chromatogram of broccoli extract, retention time $\left(\mathrm{R}_{\mathrm{t}}\right)$ values of broccoli extract were 3.00, 11.50, 14.50 respectively. Lin et al. ${ }^{3}$ studied on identification of phenolic components of collard greens, kale and Chinese broccoli, when we have compared with LC chromatograms of current study we have concluded that they were similar $\mathrm{R}_{\mathrm{t}}$ values according to HPLC chromatogram of broccoli extract (Figure 1).

HPLC chromatogram of GH can be seen in Figure 2 and $R_{t}$ value of the GH was 2.60. Table 1 was shown $R_{f}$ values of broccoli extract and GH by TLC methods. The results of HPLC and TLC analysis were compatible with each other.

Retention times of the ${ }^{99 \mathrm{~m}} \mathrm{Tc}$ and ${ }^{99 \mathrm{~m}} \mathrm{Tc}-\mathrm{GH}$ were determined by HPLRC, relatively, 3.05 and 2.60 minutes (Figure 3).
TABLE 1 - $\mathrm{R}_{\mathrm{f}}$ values of broccoli extract and GH by TLC methods.

\begin{tabular}{crrrc}
\hline & \multicolumn{2}{c}{ Broccoli extract } & GH \\
\hline Solvent & \multicolumn{2}{c}{$60 \%$} & methanol in water & Acetone \\
$\mathbf{R}_{\mathrm{f}}$ values & 0.34 & 0.70 & 0.98 & 0.94 \\
\hline
\end{tabular}




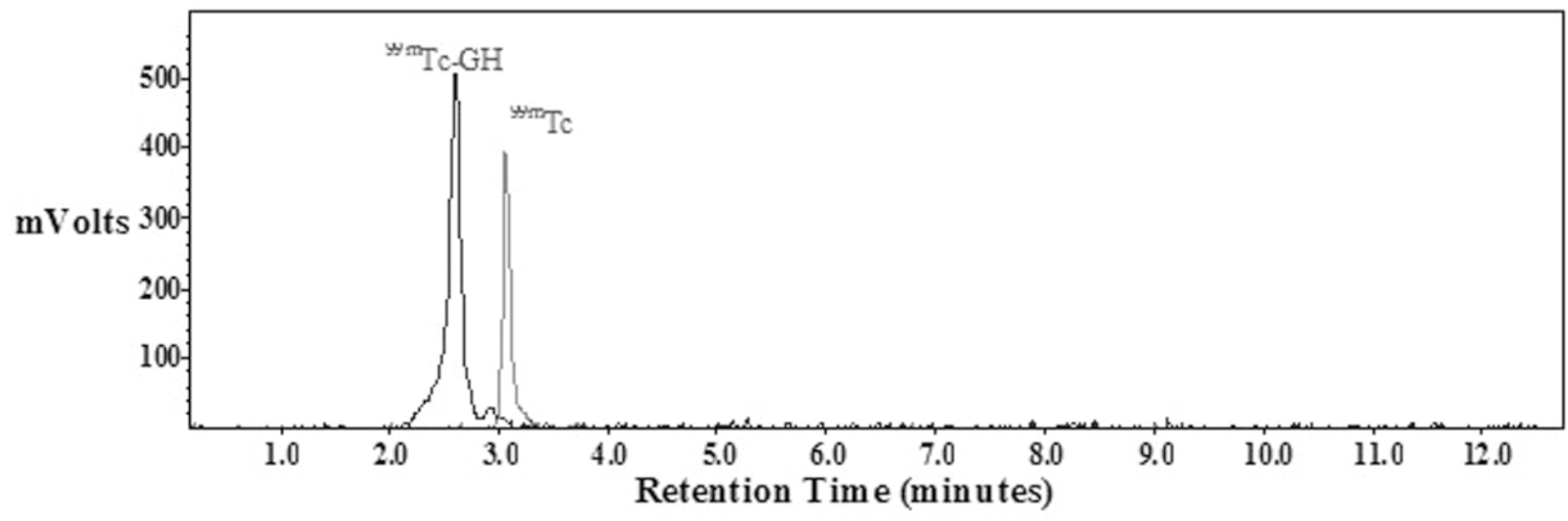

FIGURE 3 - HPLRC chromatograms of ${ }^{99 \mathrm{~m}} \mathrm{Tc}$ and ${ }^{99 \mathrm{~m}} \mathrm{Tc}-\mathrm{GH}$.

HPLRC results showed that $R_{t}$ value of ${ }^{99 m} \mathrm{Tc}-\mathrm{GH}$ was different from ${ }^{99 \mathrm{~m}} \mathrm{Tc}$. By TLRC, $\mathrm{R}_{\mathrm{f}}$ values of ${ }^{99 \mathrm{~m}} \mathrm{Tc}-\mathrm{GH},{ }^{99 \mathrm{~m}} \mathrm{TcO}_{4}{ }^{-1}$ and reduced ${ }^{99 \mathrm{~m}} \mathrm{Tc}$ were $0.91,0.92,0.03$ respectively (Table 2). High radiochemical yield $[98.46 \pm 1.48 \%(n=8)]$ was obtained by using TLRC method in SF solvent system. HPLRC and TLRC chromatograms were supported each other.

TABLE 2 - $\mathrm{R}_{\mathrm{f}}$ values of components by TLRC method.

\begin{tabular}{lccc}
\hline & ${ }^{99 \mathrm{~m}} \mathrm{Tc}-\mathrm{GH}$ & ${ }^{99} \mathrm{mcO}_{4}^{-}$ & Reduced ${ }^{99 \mathrm{~m}} \mathrm{Tc}$ \\
\hline $\mathrm{R}_{\mathrm{f}}$ values & 0.91 & 0.92 & 0.03 \\
\hline
\end{tabular}

As can be seen in Figure 4, stability studies showed that approximately $95 \%$ of ${ }^{99 m} \mathrm{Tc}-\mathrm{GH}$ existed as an intact complex within 24 hours.

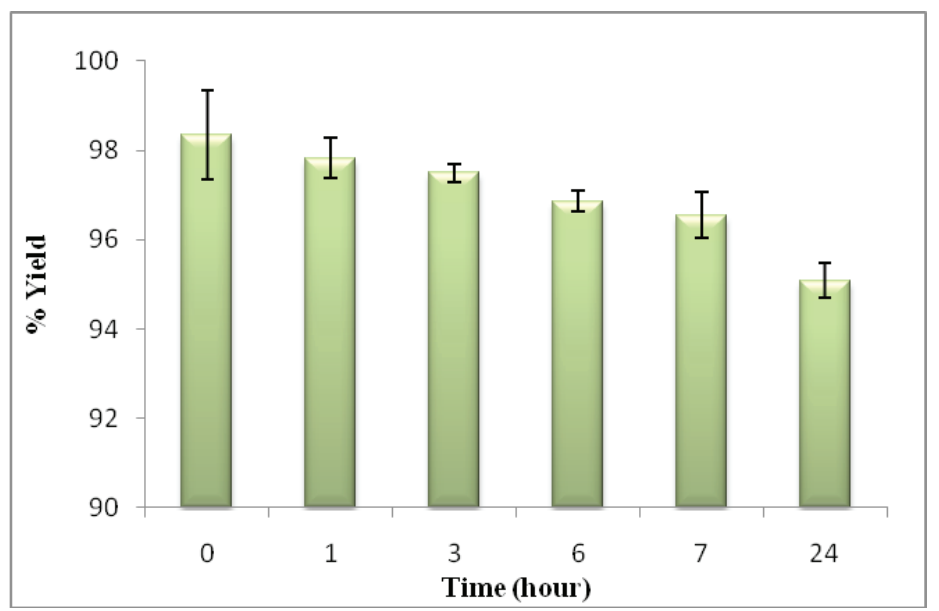

FIGURE 4 - Stability of ${ }^{99 m} \mathrm{Tc}-\mathrm{GH}$.
Theoretical $\log \mathrm{P}$ was calculated with $\mathrm{ACD} / \log \mathrm{P}$ software (Version 6.0 for Microsoft Windows) for $\mathrm{GH}$ and it was found $-4.07 \pm 0.90$. Experimental $\log \mathrm{P}$ value of ${ }^{99 \mathrm{~m}} \mathrm{Tc}-\mathrm{GH}$ was found $-2.91 \pm 0.41$. Experimental and theoretical $\log \mathrm{P}$ values of ${ }^{99 \mathrm{~m}} \mathrm{Tc}-\mathrm{GH}$ were compared. It was seen that these values were similar each other.

Table 3 represents the values obtained for the percentage of radioactivity of serum and blood cells from male Wistar rats treated with broccoli and control group. The percentage of radioactivity for $\mathrm{BC}$ of the group of treated with broccoli extract was $54.47 \pm 3.66$ and the percentage of radioactivity for $\mathrm{BC}$ of the control group 56.31 \pm 4.48 . According to this result, broccoli extract was not effected labeling blood components with ${ }^{99 \mathrm{~m}} \mathrm{Tc}-\mathrm{GH}$. It is thought that the cause of this situation is extraction method or components in the extract.

TABLE 3 - The percentage of radioactivity for $\mathrm{P}$ and RBC.

$(n=8) \quad$ Serum $(\mathrm{S}) \quad \begin{gathered}\text { Blood Cells } \\ (\mathrm{BC})\end{gathered}$

\begin{tabular}{lll} 
Control group & $43.69 \pm 4.48$ & $56.31 \pm 4.48$ \\
treated with SF & & \\
$\begin{array}{l}\text { Treated group } \\
\text { ith broccoli } \\
\text { extract }\end{array}$ & $45.53 \pm 3.66$ & $54.47 \pm 3.66$ \\
\hline
\end{tabular}

Injected dose/g organ (\%ID/g organ) of ${ }^{99 m} \mathrm{Tc}-\mathrm{GH}$ for Wistar albino rats are given in Figure 5. The treatment with 
broccoli extract significantly $(\mathrm{p}<0.05)$ modify the $\% \mathrm{ID} / \mathrm{g}$ of in particular kidney for ${ }^{99 \mathrm{~m}} \mathrm{Tc}-\mathrm{GH}$ was decreased from $43.37 \pm 4.98$ to $4.47 \pm 1.49$. No significant alteration on the $\% \mathrm{ID} / \mathrm{g}$ of tissues from heart, lung, liver, small and large intestine, stomach, spleen, brain, thyroid, testis, prostate and bone.

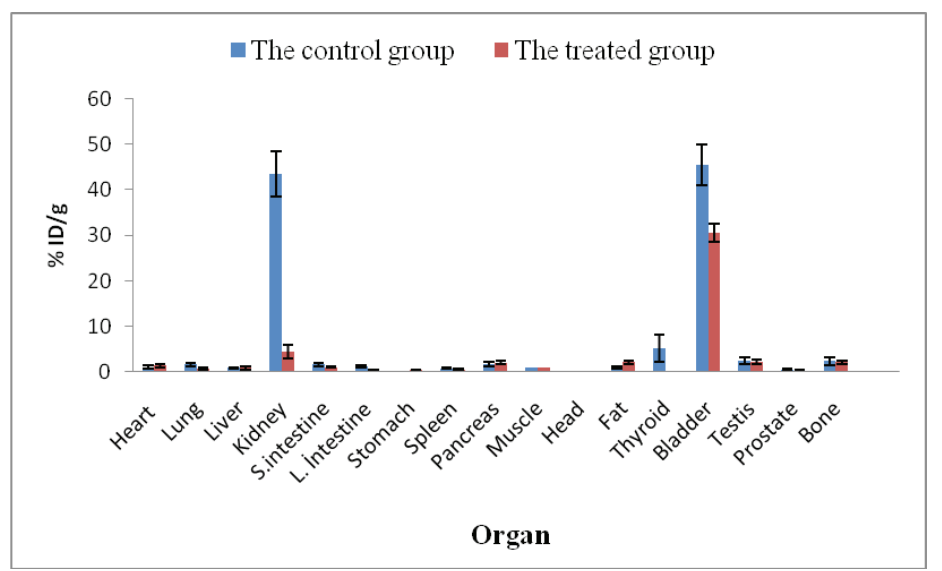

FIGURE 5 - \%ID/g of ${ }^{99 \mathrm{~m}} \mathrm{Tc}-\mathrm{GH}$ for Wistar albino rats.

\section{Discussion}

The use of natural food has increased in all over the world. Natural foods are used for the human being however several biological effects and the consequences for the health have not been well established yet ${ }^{9}$. Contrary to the numerous theoretical and practical studies of the conventionally used pharmacologically active agents, data concerning interaction of diagnostic agents, including radiopharmaceuticals, with popular medicines are relatively scarce. There are lots of researches on herbal extract interaction with radiopharmaceuticals ${ }^{10,11}$.

One of these studies was done by using cauliflower which is in the same family with broccoli. In this study the rats were treated with cauliflower extract and SF, blood samples withdrawn from the treated group and control group were labeled with ${ }^{99 \mathrm{~m}} \mathrm{Tc}$ and there is no modification labeling red blood cells (RBC) with ${ }^{99 \mathrm{~m}} \mathrm{Tc}$ in the presence of the extract ${ }^{12}$. This result supports the results obtained in our experiment. Similarly, extracts of Pfaffia sp..$^{9}$ and Passiflora edulis f. Flavicarpa ${ }^{13}$ has also not decreased the labeling of blood components with ${ }^{99 \mathrm{~m}} \mathrm{Tc}$. However, it is reported that extracts of Fucus vesiculosus ${ }^{10}$ and Cinnamomum zeylanicum ${ }^{6}$ are decreased the labeling yield of blood components with ${ }^{99 \mathrm{~m}} \mathrm{Tc}$. In addition, the study which was done using extract of guarana and ${ }^{99 \mathrm{~m}} \mathrm{Tc}-\mathrm{DMSA}$, extract was reduced the labeling yield of $\mathrm{RBC}^{11}$.

All of these studies are shown that herbal extract can affect radiolabeling of blood cells and bioavailability of radiobiocomplexes. Labeling process of blood cells depends on the presence of a reducing agent and stannous chloride $\left(\mathrm{SnCl}_{2}\right)$ is utilized with this purpose ${ }^{14}$. In these processes labeling depends on interaction between ${ }^{99 \mathrm{~m}} \mathrm{Tc}$ and stannous chloride, this interaction could be influenced from the conditions of human plasma and its components ${ }^{8}$.

There are many studies about effects of herbal extracts on biodistribution of radiopharmaceuticals ${ }^{7,13,15}$. One of them is about the effect of the P. flavicarpa extract on the biodistribution of sodium ${ }^{99 \mathrm{~m}} \mathrm{Tc}(\% \mathrm{ATI} / \mathrm{g})$ in Wistar rats. In this study, it is found that P. flavicarpa treatment induced a significant $(\mathrm{p}<0.05)$ alteration on the $\% \mathrm{ATI} / \mathrm{g}$ of tissues from duodenum, spleen, pancreas, stomach as well as blood. No alteration on the $\%$ ATI $/ g$ of tissues from brain, liver, heart, kidney, lung, bone, muscle, thyroid and testis ${ }^{13}$.

In another study, it is shown that the mint (Mentha crispa) extract increased fixation of this radiobiocomplex in the pancreas, kidney, spleen, liver, and thyroid, there is no significant alteration in other organs. The reason of this alteration was tried to explain that as the radiobiocomplex studied is an ion, the effect of the components of extract would also act in the transport of the pertechnetate ion through the cellular membrane of determined organs ${ }^{15}$. Rocha and coworkers evaluated effects of sucralose sweetener sodium pertechnetate $\left(\mathrm{Na}^{99 \mathrm{~m}} \mathrm{TcO}_{4}\right)$ and diethylenetriamine pentaacetic acid labeled with ${ }^{99 \mathrm{~m}} \mathrm{Tc}\left({ }^{99 \mathrm{~m}} \mathrm{Tc}-\right.$ DTPA) biodistribution in rats. Sucralose sweetener was capable of altering \%ATI/g of the radiopharmaceuticals in different organs ${ }^{7}$.

In literature, the changes at the biodistribution studies are explained by the presence of specific chemical compounds in the extract or by the generation of active metabolites capable to interfere with the biodistribution of the studied radiobiocomplex ${ }^{15}$.

\section{Conclusions}

Current study is an addition to other studies about herbal extract interaction with radiopharmaceuticals. Misdiagnosis and repetition of the examinations are due to these unknown interactions. If herbal extract interaction with radiopharmaceuticals is known, imaging efficiency will be conclusively and the unnecessary radiation dose which is taken by patients with repeated imaging will reduce. Consequently we can put more reliable diagnosis.

\section{References}

1. Lin J, Kamat A, Gu J, Chen M, Dinney CP, Forman MR, Wu XF. Dietary intake of vegetables and fruits and the modification effects of GSTM1 and NAT2 genotypes on bladder cancer risk. Cancer Epidemiol Biomarkers Prev. 2009;18(7):2090-7.

2. Mengesha AE, Youan BC. Anticancer activity and nutritional 
value of extracts of the seed of glinus iotoides. J Nutr Vitaminol. 2010;56:311-8.

3. Lin LZ, Harnly JM. Identification of the phenolic components of collard greens, kale, and chinese broccoli. J Agric Food Chem. 2009;57:7401-8.

4. Moreno DA, Carvajal M, Lopez-Berenguer C, Garcia-Viguera C. Chemical and biological characterization of nutraceutical compounds of broccoli. J Pharm Biomed Anal. 2006;41:1508-22.

5. Messina BA. Herbal supplements: facts and myths - talking to your patients about herbal supplements. J Perianesth Nurs. 2006;21:26878.

6. Benarroz MO, Fonseca AS, Rocha GS, Frydman JNG, Rocha VC, Pereira MO, Bernardo-Filho M. Cinnamomum zeylanicum extract on the radiolabeling of blood constituents and the morphometry of red blood cells: in vitro assay. Appl Radiat Isot. 2008;66:139-46.

7. Rocha SG, Pereira MO, Benarroz MO, Frydman JNG, Rocha VC, Pereira MJ, Fonseca AS, Medeiros CA, Bernardo-Filho M. Sucralose sweetener in vivo effects on blood constituents radiolabeling, red blood cell morphology and radiopharmaceutical biodistribution in rats. Appl Radiat Isot. 2011;69:46-51.

8. Paoli S, Dias APM, Capriles PVSZ, Costa TEMM, Fonseca AS, Bernardo-Filho M. Effects of a tomato (Solanum lycopersicum) extract on the labeling of blood constituents with technetium-99m. Rev Bras Farmacogn. 2008;18(2):190-6.

9. Fernandes JFO, Brito LC, Frydman JNG, Santos-Filho SD, BernardoFilho M. An aqueous extract of Pfaffia sp. does not alter the labeling of blood constituents with technetium-99m and the morphology of the red blood cells. Rev Bras Farmacogn. 2005;15(2):126-32.

10. Oliveira JF, Oliveira MBN, Avila AS, Braga ACS, Catanha MTJA, Jales RLC, Cardoso VN, Bernardo-Filho M. Assessment of the effect of Fucus vesiculosus extract on the labeling of blood constituents with technetium-99m and the histological modifications on the shape of the red blood cells. Food Chem Toxicol. 2003;41:15-20.

11. Freitas RS, Moreno SRF, Lima-Filho GL, Fonseca AS, BernardoFilho M. Effect of a commercial extract of Paullinia cupana (guarana) on the binding of ${ }^{99 \mathrm{~m}} \mathrm{Tc}-\mathrm{DMSA}$ on blood constituents: An in vivo study. App. Radiat Isot. 2007;65:528-33.

12. Lima EAC, Dire G, Mattos DMM, Freitas RS, Gomes ML, Oliveira MBN, Faria MVC, Jales RL, Bernardo-Filho M. Effect of an extract of cauliflower (leaf) on the labeling of blood elements with technetium-99m and on the survival of Escherichia coli AB1157 submitted to the treatment with stannous chloride. Food Chem Toxicol. 2002;40:919-23.
13. Rebello BM, Moreno SRF, Godinho CR, Neves RF, Fonseca AS, Bernardo-Filho M, Medeiros AC. Effects of Passiflora edulis flavicarpa on the radiolabeling of blood constituents, morphology of red blood cells and on the biodistribution of sodium pertechnetate in rats. Appl Radiat Isot. 2008;66:1788-92.

14. Costa TEMM, Dias APM, Capriles PVSZ, Oliveira MBN, Amorim ELC, Lima CSA, Bernardo-Filho M. Effect of barbatimão [Stryphnodendron adstringens (Mart.) Coville] infusion on the labeling of blood elements with technetium-99m. Rev Bras Farmacogn. 2002;12:7-9.

15. Santos-Filho SD, Maiworm AI, Presta GA, Paoli S, Giani TS, Bernardo-Filho M. Aqueous extract of the medicinal plant Mentha crispa alters the biodistribution of the radiopharmaceutical sodium pertechnetate in Wistar rats. Med Chem Res. 2007;16:23

\section{Correspondence:}

Fazilet Zumrut Biber Muftuler

Department of Nuclear Applications, Institute of Nuclear Sciences

Ege University, 35100 Bornova, Izmir, Turkey

Tel: +902323112495

Fax: +90 2323886466

fazilet.zumrut.biber@ege.edu.tr

fazilet.zumrut.biber@gmail.com

Received: INDICAR

Review: INDICAR

Accepted: INDICAR

Conflict of interest: none

Financial source: Ege University Research Fund 